B. Millikan, is professor of aeronautics at the California Institute of Technology. His second son, Glenn A. Millikan, who was professor of physiology at Vanderbilt University, was killed in a mountainclimbing accident in 1947. Glenn Millikan's wife was Claire Mallory, daughter of George Leigh Mallory, the Mount Everest climber. His youngest son, Max F. Millikan, is professor of economics in the Massachusetts Institute of Technology.

Robert B. Brode

\section{Prof. Oldřich Tomíček}

Prof. O. Tomf̌̌Ek's death, which occurred after a short illness on October 21 a few days after his sixtysecond birthday, is a heavy blow to Czechoslovak analytical chemistry, for during the past twenty-five years he has been the leading analyst and pharmacist at the Charles University. He was born in Prague on October 10, 1891, where his father was a pharmacist, and early showed his scientific ability in publications with Prof. B. Brauner. Thus young Tomíček was predestined to the study of pharmacy and reached the degree of Pharmaciae Magister shortly before the outbreak of the First World War, in which he had to serve in a military pharmacy in Innsbruck. It is significant of the zeal of the young scientist that he found an opportunity of approaching Prof. K. Bruner to pursue special work on indol derivatives in the laboratories of the University of Innsbruck. The end of war brought Tomícek back to Prague and gave him the chance to widen his scientific knowledge at the Charles University under the guidance of the inorganic chemist Prof. SterrbaBöhm. Here he took the degree of Ph.D. in June 1920 and was appointed university assistant. The years 1923-24 Tomíček spent in Utrecht in the laboratory of Prof. Schoorl to acquire potentiometry. There started his friendship with the rising scientist, I. M. Kolthoff, which proved most influential for the further development of Tomíček's line of research and lasted-supported by frequent meetings of both men at various international gatherings-until Tomíček's death. The two friends worked out the foundations for the use of titanous chloride in potentiometric titrations.

Later on, as assistant professor of analytical chemistry in Prague, Tomíček worked on the potentiometric determination of cerium and started with his school a series of studies of volumetric determinations in strongly alkaline medium. His chief work in that direction was published in the Journal of the American Chemical Society during 1935, where he gave practical applications for the titrations of cobalt, manganese, bismuth, thallium and cerium, using amalgams for the reduction, and ferricyanide, hypochlorite or hypobromite for oxidation. In that year Tomícek was nominated full professor.

In 1943 he started to study potentiometric and polarometric titrations in non-aqueous solutions, chiefly in glacial acetic acid. This line of research required special attention from the theoretical aspect as regards the meaning of neutralizations and $p \mathrm{H}$ values. These discussions are therefore of high theoretical value and of fundamental interest, promising also possibilities of wide practical applications.

Prof. Tomíček was also held in high regard in pharmaceutical circles, being co-editor of the Czechoslovak "Pharmacopœia" and revising the analytical problems involved. He was expert also in forensic chemistry.

As a university teacher, Tomícek proved an excellent lecturer, devoted to his pupils. For them he wrote in Czech several valuable text-books on quantitative and volumetric analysis. Of his scientific monographs the best known and appreciated is "Chemical Indicators", which was translated into English (Butterworth, London, 1951). Besides this, Tomícek contributed at the international level to the "Handbuch der analytischen Chemie" (J. Springer, Berlin, 1944 and 1948) with accounts on ammonium, oxygen, sulphur, selenium and tellurium. In his own country, also, Prof. Tomíček was highly esteemed. For many years he was president of the Czechoslovak Chemical Society, of which he was made an honorary member, president of the Pharmaceutical Society and corresponding member of the Czechoslovak Academy of Science.

Tomíček was an extremely kindly man, always willing to help his numerous friends, colleagues and pupils, and inclined to overwork himself for unselfish reasons. His non-academic interests were mountaineering, motoring and skiing. Thus not only in scientific minds, but also in many hearts, Prof. Tomiček's death has left an open gap.

\section{J. HEYROVSKÝ}

\section{Dr. F. C. Minett, C.I.E., M.B.E.}

Dr. F. C. Minetr, director of the farm livestock research station of the Animal Health Trust, died on December 26 at the age of sixty-three.

Francis Colin Minett was born on September 16, 1890, and was educated at King Edward's School, Bath, the Royal Veterinary College, London, and the Pasteur Institute, Paris. He qualified as a veterinary surgeon in 1911 and worked for the next three years in the pathology department of the Royal Veterinary College under Sir John MeFadyean. During 1914-24 Minett was an officer in the Royal Army Veterinary Corps. He then became a research officer of the Ministry of Agriculture's veterinary laboratories until 1927, when he was appointed director of the Research Institute of Animal Pathology at the Royal Veterinary College; in 1932 he became professor of pathology. In 1939 Minett went to India as director of the Imperial Veterinary Research Institute at Mukteswar. On the division of India he became commissioner for animal husbandry in Pakistan until 1949, when he joined the staff of the Animal Health Trust. At the request of the Foreign Office, he was soon seconded for two years as veterinary adviser to the Turkish Government.

Minett was a prodigious worker, mainly upon bacteriological problems concerned with disease in animals. He was a strenuous bench worker throughout his life, although he never neglected-indeed he encouraged-the translation of laboratory work to the farm. His work was mainly concerned with diseases of cattle, and he studied in turn bovine tuberculosis, contagious bovine abortion, Johne's disease, foot and mouth disease and mastitis. $\mathrm{He}$ also investigated mastitis in sheep, blackquarter, anthrax, strangles in horses, mortality wastage among livestock in India, and the health of animals as affected by climatic conditions. In all, he published more than fifty papers in scientific journals.

Probably the main work which Minett did was to focus attention on the serious loss in Great Britain occasioned by mastitis in cattle. He divided the 
Streptococcus forms into three groups, and it was shown that his Group I coincided with Str. agalactiae, information which was already known in other countries. He and his colleagues were the first to point out the etiology of his Group II, which is known as Str. dysgalactiae. His Group III is now known as Str. uberis. Probably the best defence that Minett ever gave for the work which he and his colleagues did is in an article published in the Journal of Hygiene, 35, 504 (1935). This was in answer to an attempt by some medical bacteriologists to delve into a veterinary problem. His work also included the demonstration that certain human strains of Streptococei could affect the udder of the cow, and in turn that affected milk may cause an outbreak of human disease. He directed attention to the toxin production of Staphylococci of animal sources ; these differ in some degree from the human pathogens. His work on Johne's disease was largely concerned with methods of isolation and types of media, in addition to collaborating with others in the diagnosis of the disease, particularly by Johnin.

Minett was a strenuous worker, who expected equal work from his junior colleagues; he appeared stern, but beneath an apparently hard exterior he was warm-hearted and full of fun. His early death is a great loss to British veterinary science.

W. R. WOOLDRIDGE

\section{NEWS}

Mr. Cecil Warburton: 100th Birthday

ON February 6, Mr. Cecil Warburton celebrated his hundredth birthday. Mr. Warburton entered Christ's College, Cambridge, in 1876. He became a demonstrator in the School of Agriculture and in the Department of Zoology in the University, and later he was a member of the Quick Laboratory which eventually grew into the Molteno Institute. Mr. Warburton has always had wide interests in general entomology and was for many years honorary zoologist to the Royal Horticultural Society (of which he was elected a life member at the age of ninety-six). He has published papers, etc., on spiders, and wrote the section on Arachnidæe in the "Cambridge Natural History" (Macmillan). Perhaps his best-known scientific work is on the ticks, in collaboration with the late Prof. G. H. F. Nuttall, which led to the production of the standard monograph on this economically important group of animals. For many years now, Mr. Warburton has been a living confutation of the gerontologists, for he has maintained in almost legendary degree his activity of body and of mind - at least he still plays bridge and chess (at which many years ago he represented the University of Cambridge), he is still a dangerous opponent at croquet, and solves The Times crossword puzzle each day. At the luncheon given in his honour on the eve of his birthday by his old College, he responded with a lively speech; he was also entertained at luncheon on his birthday by his colleagues at the Molteno Institute of Parasitology.

\section{Geology at Belfast :}

Prof. J. K. Charlesworth

Although The Queen's University in Belfast has an ancestry going back more than a hundred years, its chair of geology was founded only in 1921. The first occupant, Prof. J. K. Charlesworth, this year retires from the service of the University in the proud knowledge that the task of creating a department almost from its foundations is visibly fulfilled in the newly completed building that forms such an adornment to the University's post-war fabricthough it must be a source of keen regret to him that he has been able to occupy his new rooms for so short a time. After graduating at Leeds under P. F. Kendall, Prof. Charlesworth carried out research and obtained his doctorate at Breslau. He finally moved to Belfast from a senior lectureship at Manchester. His academic interests have been mainly in Pleis. tocene geology, especially in the history of the Ice Age in Britain; and his work has achieveci world.

\section{nd VIEWS}

wide distinction for the manner in which he has elucidated late-Glacial changes and described the deposits of the Newer Drift in England and Wales, the recession of the ice in southern Scotland, and the intricacies of successive glaciations in Ireland. These contributions will shortly be rounded off with an elaborate analysis of the glaciation of the Scottish Highlands. In ancillary studies he has discussed the origin of the Irish Sea and of the Irish fauna and flora. He has, however, never been narrowly content with specialist interests, but has used his position to popularize geology as a cultural subject, not least through his recently published book on the geological history of Ireland.

Dr. Alwyn Williams

Prof. Charlesworth is to be succeeded by Dr. Alwyn Williams, a graduate and former Fellow of the University of Wales. While at Aberystwyth, he elucidated the complex structures of the classical Llandeilo district, and began his studies in Lower Palæozoic fossils. Thereafter he spent a year at the Sedgwick Museum, Cambridge, with Prof. W. B. R. King. In 1948 he went with a Commonwealth fellowship to the United States National Museum, Washington, where he worked with Dr. G. A. Cooper on fossil brachiopods, a group in which his main interest lies. Some of his researches on the morphology and taxonomy of protrematous forms have been the subjects of monographs issued by the American Geological Society. Since 1950 he has been lecturer in geology in the University of Glasgow, and has extended his work on Lower Pelæozoic rocks from Wales to the Southern Uplands. The wide outcrop of similar rocks running south and south-west from Belfast will give him further opportunities of applying his special knowledge when he takes up his appointment in Ireland.

\section{Physics in the National Physical Laboratory: Dr. Ezer Griffiths, O.B.E., F.R.S.}

Dr. Ezer Griffixhs recently retired on his sixtyfifth birthday from his position as a senior principal scientific officer in the Physics Division of the National Physical Laboratory. Appointed shortly before the First World War, Dr. Griffiths had already done outstanding postgraduate research work at University College, Cardiff, which had culminated in two papers (Phil. Trans. Roy. Soc.) on the heat capacities of metals, written jointly with Principal E. H. Griffiths. These early interests have been maintained, for Dr. Griffiths has been in charge of the work on heat 